\title{
SUSTAINABLE WASTE MANAGEMENT WITH MECHANICAL BIOLOGICAL TREATMENT AND ENERGY UTILIZATION
}

\author{
Bojan Plavac, Veljko Filipan, Igor Sutlović, Jure Svetičič
}

Professional paper

A successful example of sustainable waste management applicable to towns or regions with more than two hundred thousand inhabitants is discussed. Modern landfill with composting facility, mechanical biological treatment and energy utilization of waste in the town of Celje, Slovenia, covering the needs of 24 surrounding municipalities, is described in details. The advantages, but also some difficulties that were indicated during the operation of the system are shown. Applied processing technology significantly reduces waste, extracts secondary raw materials and uses waste as an energy source, so achieving a sustainable system for a number of years. According to this successful example, our aim is to encourage similar projects in Croatia as well.

Keywords: composting; energy utilization; mechanical biological treatment; waste management

Održivo gospodarenje otpadom s mehaničko biološkom obradom i energetskim iskorištavanjem

Stručni članak

U radu se razmatra uspješan primjer održivog gospodarenja otpadom primjenjiv za gradove odnosno regije s dvjestotinjak i više tisuća stanovnika. Detaljno je opisano suvremeno odlagalište s kompostanom, mehaničko biološkom obradom i energetskim iskorištavanjem otpada u gradu Celju koje pokriva i potrebe 24 okolne općine. Ukazano je na prednosti, ali i neke poteškoće koje su se pokazale tijekom rada sustava. Ovo odlagalište primijenjenom tehnologijom obrade znatno smanjuje količinu otpada, izdvaja sekundarne sirovine te koristi otpad kao energent, čime se postiže održivi sustav za dulji niz godina. Želja nam je da se na temelju ovog uspješnog primjera potaknu slični projekti gospodarenja otpadom i u Hrvatskoj.

Ključne riječi: energetsko iskorištavanje; gospodarenje otpadom; kompostiranje; mehaničko biološka obrada

\section{Introduction}

In order to satisfy the law and regulations dealing with the environment and the waste, it is necessary to improve waste management practice. According to this, regional centres for more than two hundred thousand inhabitants were proposed as a long-term solution of the problem of waste in Slovenia. Thus, 24 municipalities in the province of Savinjska joined the EU funded project of the regional waste management centre Celje. As a result a comprehensive waste management system for entire region with 230000 inhabitants was built [1], and is successfully operating since 2009. Applied method enables reducing the waste that has to be disposed at landfill, protects against odours and hazardous substances in air, water and soil, and reduces the amount of greenhouse methane gas (which is normally produced in landfills and whose greenhouse effect is about 20 times larger than that of $\mathrm{CO}_{2}$ ). The entire project of constructing the required infrastructure in Celje cost 56 million EUR including VAT and was co-financed with $52 \%$ funding from the EU funds, $12 \%$ was provided by the state Slovenia, while $36 \%$ was provided by the community of local municipalities. With the aim to be applied as a good solution for Croatian situation, this successful example of waste management is shown in details in the paper.

\section{Waste collection}

Prior to and during the construction of the infrastructure for waste treatment in Celje, large improvements in separate collection of waste were established in Slovenia. At the consumer's level (door to door) there are used separate bins for packaging waste, bins for biodegradable waste and bins for mixed municipal waste. At the community level, separate waste fractions are collected in smaller and larger collection centres. Fractions collected include paper, glass, bulky waste, hazardous waste and other waste streams that require special treatment in accordance with the legislation. Smaller waste streams are handed over to different recycling companies, while major municipal waste streams undergo treatment in waste management centres: biodegradable waste in composting plant, paper and packaging waste in the sorting plant and rest of municipal waste in the mechanical biological treatment.

Purity of individual waste streams and also the percentage of separate collection are steadily improving. Four different waste collection companies collect municipal waste over the area of 24 municipalities and use the infrastructure of Regional waste management centre Celje, but their systems are not entirely identical. Adopting new strategies in accordance with EU legislation through the whole country, wider solutions for waste collecting and management are still taking place.

\section{The landfill}

Regional landfill of the town of Celje and 24 surrounding municipalities is located about $4 \mathrm{~km}$ east of the city of Celje, about 600 metres from the first houses of the village Bukovžlak. Its capacity $\left(1878000 \mathrm{~m}^{3}\right)$ enables the waste disposal for the next 30 years, when applying the established management system. After processing, only $25 \%$ of the mixed municipal waste is landfilled.

The bottom of the new landfill is covered with sand, and is coated with an impermeable foil to prevent spreading of drainage water beneath the surface of the landfill to the groundwater. The tires separated from the waste serve as a protective barrier and are put directly on the impermeable foil to keep it from damaging with the waste. The excavator compactors cover the landfill to 
prevent it of the spread of odours, collecting the insects, and other undesirable phenomena that can arise from uncontrolled waste disposal. Compactors also compress the deposited material, reducing its volume. Because there is no oxygen in this compressed material the possibility of inflammation is reduced to minimum [2]. New regional landfill is located next to the old one, which was in operation since 1971 .

The old landfill with the total capacity of 1700000 $\mathrm{m}^{3}$ was provided for 12 municipalities with 120000 inhabitants and is still partially in use. It uses impermeable foil only on one part but there is the clay for reducing permeability of the drainage water generated in the landfill by atmospheric precipitation. There are also pipes for collecting and drain the landfill gases generated by anaerobic decomposition of waste. Formerly these gases were burned in a flare, and now they are used in two internal combustion engines for production of electric energy in the capacity of 1,5 MW. The thermal energy from these engines is used for space heating in the MBT plant. In the case of failure of engines, landfill gases can be burned in the existing flare.

In general, the deposited waste at the landfill undergoes the transformation in two stages [3]. In the first stage, the organic matter in the waste is converted into humic substance, and in the second stage the humic substance becomes the mineral matter. During this process, an important role has the aerobic fermentation which takes place on the surface of the deposited waste. The process of fermentation generates the heat and so the temperature rises up to 70 or $90{ }^{\circ} \mathrm{C}$. In deeper landfill layers, where air circulation is impossible, the anaerobic fermentation takes place. This process rises the temperature of the waste up to 35 or $40{ }^{\circ} \mathrm{C}$. By fermentation processes, around $60 \%$ of the waste is transformed into the compost - a substance rich with carbon, nitrogen, potassium and magnesium, but also microelements and heavy metals.

Due to the infiltration of rain and release of the primary moisture deposited in the waste, a certain amount of water that gradually dissolves soluble components from waste and compost is accumulated [4]. This water as a solution of complex, often highly toxic, chemical composition is drained into the lower part of the landfill. The filtrate is potentially dangerous for groundwater $[5 \div 8]$. To prevent this effect, there is a system of pipes for the collection of the leachate, and additionally, the wells for monitoring the composition of water beneath impermeable foil are placed nearby. The collected leachate is treated at leachate processing device, which is located about $300 \mathrm{~m}$ from the landfill downwards. The leachate is purified by membrane technology to a level that is allowable (by law) for discharging into the sewage system (Fig. 1).

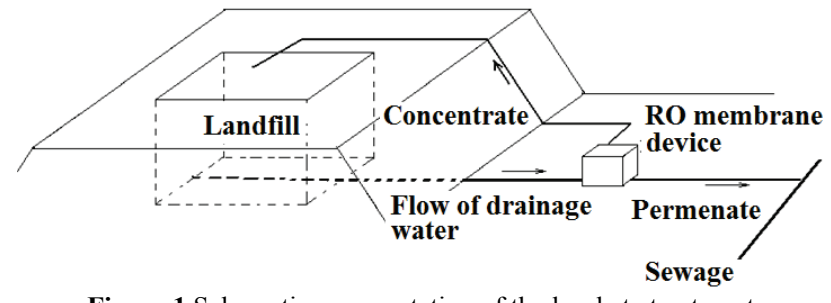

Figure 1 Schematic representation of the leachate treatment
The separation mechanism of reverse osmosis is based on the difference in the diffusion of substances to be separated and the solvent (water). It is one of the pressure membrane processes with pressure gradient as the driving force $[9,10]$. The purified water is passing through the membranes and is discharged to sewage, and the concentrate produced in the process is sent back to the landfill (Fig. 1).

\section{Mechanical biological treatment (MBT)}

Mechanical biological treatment designs are very versatile, depending on the type of input waste and the required goals.

In different MBT systems waste passes through various processes, but the processing is generally divided into two main stages: (1) mechanical and (2) biological treatment. In the mechanical part, waste is treated physically by processes such as crushing, grinding, milling, and similar physical treatment processes. In biological treatment biological processes occur in the waste which is biodegraded by drying out and similar processes [11]. In this part of MBT waste can be converted into compost or secondary source of energy (fuel) $[12,13]$. Biological treatment can be carried out using one of the following processes: anaerobic digestion, composting or bio drying $[14,15]$. In an anaerobic process there are used micro-organisms that break down the waste components and produce biogas and soil improvers. Biogas can be used for production of electricity and heat. In the composting process, the aerobic treatment occurs where the microorganisms do not produce fuel, but create the carbon dioxide and the compost. In the third mode, bio drying, the aerobic microorganisms produce the heat and dry the waste, which then becomes convenient for further processing $[14,15]$. The resulting heat created in biochemical reactions within micro-organisms during aerobic biodegradation of waste removes moisture and biodegradable part of waste [16].

The purpose of the composting process is to produce a stable final product, i.e. compost which can be disposed off without environmental consequences or can be further used for improving the soil. Untreated municipal solid waste whose organic fraction is not stabilized may cause the formation of methane gas during anaerobic digestion.

The potential of creating methane in the waste is timely dependent. The relationship between the methane production potential ( $A B P$ in \% of the starting potential) and the time ( $t$ in days) can be mathematically described by the following equation [17]:

$$
A B P=78,516 \cdot \mathrm{e}^{-0,0123 \cdot t} \quad\left(R^{2}=0,8\right) .
$$

Using Eq. (1) the remaining ABP depending on the duration of the bio-stabilisation process at the landfill can be calculated and results are presented in Tab. 1 . It can be seen that the remaining ABP after 1 month is about $54 \%$, and after 6 months is only $9 \%$, while after 1 year is practically negligible. On the other hand, if the process of bio-stabilization is longer, the consumption of electrical energy and operating and maintenance costs are higher. 
The practice with the duration of the bio-stabilization process of waste in different countries is different. For example in Italy, bio-stabilisation process takes approximately 2 to 4 weeks, giving the product that is middle stabilized [17]. But, in Austria, Germany, and England, bio-stabilisation process lasts from 2 to 6 months, thus getting highly biologically stable compost that is landfilled $[17,18]$.

Table 1 Remaining ABP potential depending on the biostabilization

\begin{tabular}{|c|c|}
\multicolumn{2}{|c}{ process duration } \\
\hline Duration of the treatment & $\begin{array}{c}\text { Remaining ABP } \\
\text { /\% of starting ABP }\end{array}$ \\
\hline 2 weeks & 65 \\
\hline 4 weeks & 54 \\
\hline 2 months & 38 \\
\hline 6 months & 9 \\
\hline 1 year & $<1$ \\
\hline
\end{tabular}

MBT plant in Celje with the capacity of 62000 tons per year is designed so that the mixed municipal waste is biologically treated first, and after that it is mechanically treated. In biological treatment, composting and bio drying take place at the same time. The plant is located on the same plateau with sorting and storage plant (Fig. 2).

One part of the joint object is used only for composting of biodegradable waste (the waste from gardens and parks), while the MBT plant is in the second part (Fig. 3).

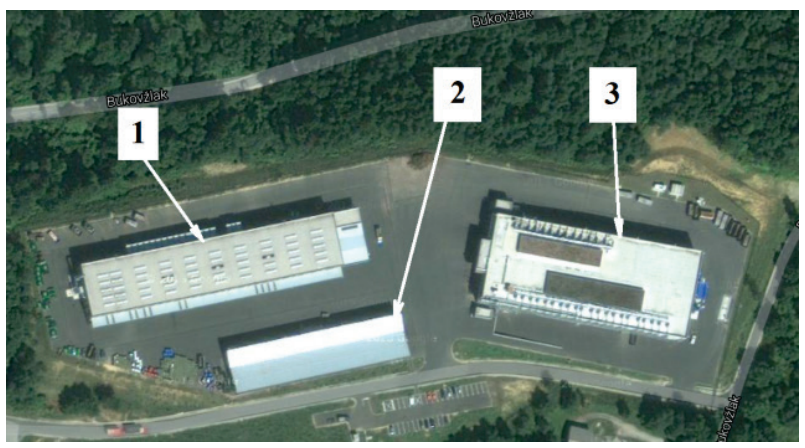

Figure 2 Satellite view of sorting plant (1), storage place (2), and composting and MBT plant (3)

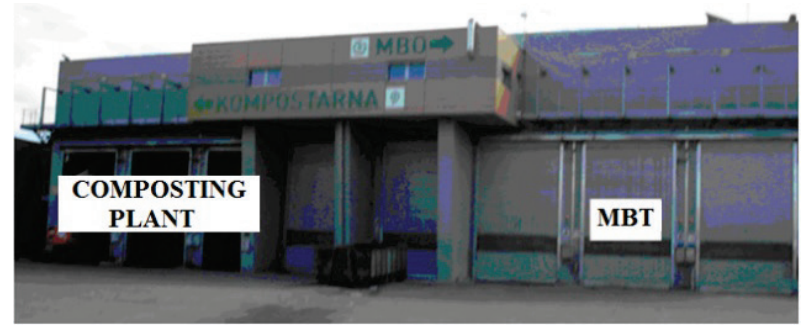

Figure 3 View of the entrance area of a joint object for composting and MBT plant

The treatment process with the mixed waste brought to the MBT plant is shown in Fig. 4. The waste transported by trucks is unloaded into the entrenched building (1) and then it is transferred by a special crane to the drum sieve (2) for material separation by size. Parts smaller than $12 \mathrm{~cm}$ go on to the stabilization and bio drying (3), where they are treated for 14 days. Parts greater than $12 \mathrm{~cm}$ are transported to further mechanical processing ( 6 and thereafter).
During bio stabilization and bio drying (bio treatment) waste loses its weight (about $25 \%$ ) due to oxidation carried out by micro-organisms, while a part of the waste converts into $\mathrm{CO}_{2}$ and $\mathrm{H}_{2} \mathrm{O}$. Once it passes bio stabilization and bio drying, the remaining material is subjected to mechanical processing. Waste is further fragmented in a shredder (6) and then sieved on fine drum rotary sieve (7), where stabilized waste (soil, etc.) is segregated. Most of the remaining waste passes through the air separator (10) where heavy and light fractions are separated. The heavy fraction (about $25 \%$ ) is transported to the biostabilization plant prior to landfilling (8), and the light fraction, after the grinding (11) and separation of metals on magnetic separator (12) and the induction separator with eddy current (14), is collected and transported by trucks (15) in the heating plant.

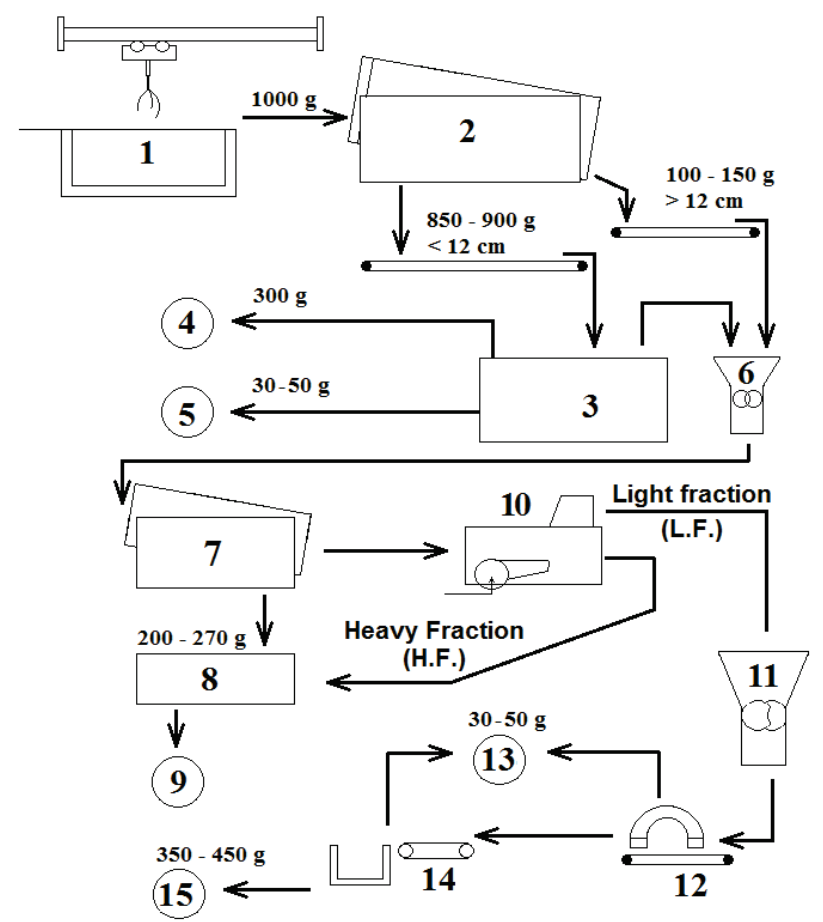

Figure 4 Schematic representation and the material balance for MBT plant (1 - Building for the delivery of waste, 2 - Drum sieve, 3 Biostabilization and biodrying, 4 - Water, 5 - Remains, 6 - Shredder, 7 Drum sieve, 8 - Biostabilization prior to landfilling, 9 - Landfill, 10 - Air separator, 11 - Shredder, 12 - Magnetic separator, 13 - Metals, 14 -

Inductive eddy-current separator, 15 - Fuel for the heating plant)

The whole described process takes place in an enclosed facility that is under negative pressure to prevent the release of odours. Unpleasant odours are processed in bio filters that are placed on the roof of the building where the pollution from the air intake of the building adsorbs and diffuses within the biofilm layer. Biofilm is represented by micro-organisms that are fed with pollution and generate $\mathrm{CO}_{2}, \mathrm{H}_{2} \mathrm{O}$, heat and new cells. Biofilters used in the MBT plant in Celje do not have an automatic humidifier that is required for maintaining the wetness, and so the plant staff checks the operation of the plant bio-filters and if necessary moistens them with water (especially during hot and dry weather). Wooden reeds are used as filler for micro-organisms developing. After forming on fillers, bio film can be operational for about 3 to 5 years before changing. 
Prior to landfilling, material undergoes the process of biostabilization in a plant (Fig. 5) located near the landfill. Biostabilization plant was additionally built in 2015 to meet the stricter legislation requirements for biological stability of landfilled waste, which were not achieved in two weeks of bio drying process within the existing MBT plant. Biostabilization plant is a basic tent covered hall where material is turned with a compost turner, ventilated and irrigated for 6 weeks, after which the stabilized waste is transported to the landfill.

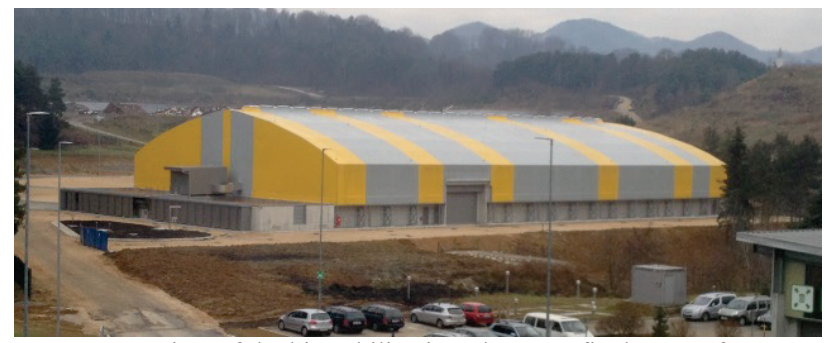

Figure 5 View of the biostabilization plant as a final stage of MBT

After the MBT process in Celje, the $25 \%$ of the remaining mixed municipal waste to be landfilled meets the following thresholds: TOC $<18 \%$ d.m., calorific value $<6 \mathrm{MJ} / \mathrm{kg}$ d.m and $\mathrm{AT}_{4}<10 \mathrm{mgO}_{2} / \mathrm{g}$ d.m, whereas calorific value of light fraction that is transported to the heating plant varies from 20 to $25 \mathrm{MJ} / \mathrm{kg} \mathrm{d.m}$.

Obligatory analysis of input mixed municipal waste ceased as of 2011, so information is limited. Last analysis of mixed municipal waste from June 2011 showed the composition of $52 \%$ biodegradable, $27 \%$ plastics, $16 \%$ interts, and $5 \%$ indistinguishable [19]. Input waste is heterogeneous but overall seasonal variations of main types of materials are low. With increased efficiency of separate collection, composition of input waste is changing towards less calorific value.

\section{Composting plant}

The separately collected biodegradable waste (kitchen and yard waste) is treated in the composting plant. The capacity of the plant is 12000 tons per year and this waste is converted into compost which better quality can be sold for soil improvement, while poorer compost is disposed of for covering the landfill. In the process of composting the substrate is ventilated and the air is flowing through the material under a slight vacuum.

Composting process is monitored by measuring the temperature of the compost. When the temperature increases (due to the biological processes within the compost) the air flow through the waste has to be increased, and if the temperature of the compost falls down, the air flow must be reduced. Therefore nearly constant temperature in the process (around $60^{\circ} \mathrm{C}$ ) can be maintained by the controlled rotational speed of the fans electric motors. The necessary duration of composting process to reduce the moisture content to the required level is usually about two weeks. If the process is stopped earlier or if the compost is dried too early, biological composting processes would not be completed. To avoid premature drying of compost, water that occurs as leachate is added to the compost. Some MBT facilities have a special filter for such waste water, but in the plant in Celje the water is simply recirculated, wherein a part of it evaporates during the composting process.

\section{Sorting}

The other separately collected waste fractions from households are brought to the sorting plant with the capacity of 10000 tons per year to be sorted into clean fractions ready for recycling.

Firstly, the material is prepared for the most efficient sorting. This includes the bag opener, conveyor belt steps for an even spread of material and a $20 \mathrm{~mm}$ sieve to remove small particles.

Waste is manually sorted by workers working at the conveyor belt. The sorted fractions include different types of polymer materials (especially HDPE, LDPE, PET, PES), paper and cardboard. Metals are automatically sorted using magnetic and inductive separator.

Sorted waste fractions are handed over to different specialized recycling companies, while remaining material is forwarded to the MBT plant for further treatment.

\section{Energy utilization - Heating plant}

The heating plant Celje is located $3,13 \mathrm{~km}$ east from the MBT plant and landfill. The separated light fraction from MBT plant is transported by trucks to the heating plant for energy utilization. There are about 10 to 12 trucks per day. The exact mass of brought light fraction is determined by measuring the weight of the truck before and after unloading at the heating plant. Besides the light fraction from the MBT plant, sludge from the municipal wastewater treatment plant is also transported to the heating plant. The sludge with very low calorific value (about $0,4 \mathrm{MJ} / \mathrm{kg}$ ) is mixed with the light fraction to obtain a mixture of fuel with a caloric value of about 16 $\mathrm{MJ} / \mathrm{kg}$, which is then burned in the combustion chamber (furnace) of the boiler. Daily container of light fraction in the heating plant is a dug building with the depth of $7 \mathrm{~m}$. There is a crane for taking the waste and an automatic system for odours control. Incurred odours are removed by suction of the complete combustion air from this space by fans. So, there is no need for special bio-filters like those in MBT plant.

Generally, the combustion process depends on the type of waste (fuel), fuel preparing, and the design of the combustion chamber and combustion installations [20]. For the design of the burning process it is also important to know the specific thermal characteristics, such as the Arrhenius coefficient $\left(A_{\mathrm{r}}\right)$ and the activation energy $\left(E_{\mathrm{a}}\right)$ of the specific fuel. These characteristics can be determined experimentally, and their values can help in the calculation of the required temperature and the retention time of burning the fuel in the combustion chamber. The following theoretical relation is derived:

$\ln \Delta t=\ln \frac{9,21}{A_{\mathrm{r}}}+\frac{E_{\mathrm{a}}}{R \cdot T}$,

where $\Delta t(\mathrm{~s})$ represents the required time for the fuel in combustion chamber (boiler furnace), $T(\mathrm{~K})$ is the 
absolute temperature of the combustion process and $R$ is the molar gas constant $R=8,314\left(\mathrm{Jmol}^{-1} \mathrm{~K}^{-1}\right)$ [20]. Eq. (2), as a general mathematical model that gives insight into the theoretical combustion process, is based on the theoretical oxidation reaction rate. This can be described by a first order reaction and its kinetics is based on the Arrhenius equation taking into account the balance of matter. Therefore, it is clear that the type of fuel has an important impact on the design of the combustion chamber and process. Tab. 2 gives the thermokinetic parameters (Arrhenius factor and activation energy) for different substances [20, 21] and retention times calculated for 2 different temperatures in the combustion chamber or the boiler furnace $\left(700^{\circ} \mathrm{C}\right.$ and $\left.1065^{\circ} \mathrm{C}\right)$.

Table 2 Thermokinetic parameters and necessary retention times $\Delta t$ for 2 different temperatures $\left(700^{\circ} \mathrm{C}\right.$ and $\left.1065^{\circ} \mathrm{C}\right)$

\begin{tabular}{|c|c|c|c|c|}
\hline $\begin{array}{c}\text { Substance, } \\
\text { chemical } \\
\text { formula }\end{array}$ & $\begin{array}{c}\text { Arrhenius } \\
\text { factor } \\
/ \mathrm{s}^{-1}\end{array}$ & $\begin{array}{c}\text { Activation } \\
\text { energy } \\
/ \mathrm{J} \mathrm{kmol}^{-1}\end{array}$ & $\Delta t_{700^{\circ} \mathrm{C}} / \mathrm{s}$ & $\Delta t_{1065^{\circ} \mathrm{C}} \mathrm{s}$ \\
\hline Benzene, $\mathrm{C}_{6} \mathrm{H}_{6}$ & $7,43 \times 10^{21}$ & $4,015 \times 10^{8}$ & 4,4 & $5,8 \times 10^{-6}$ \\
\hline $\begin{array}{c}\text { Chlorobenzene } \\
\mathrm{C}_{6} \mathrm{H}_{5} \mathrm{Cl}\end{array}$ & $1,34 \times 10^{17}$ & $3,207 \times 10^{8}$ & 11,3 & $2,3 \times 10^{-4}$ \\
\hline Ethane, $\mathrm{C}_{2} \mathrm{H}_{6}$ & $5,65 \times 10^{14}$ & $2,663 \times 10^{8}$ & 3,2 & $4,1 \times 10^{-4}$ \\
\hline $\begin{array}{c}\text { Ethanol, } \\
\mathrm{C}_{2} \mathrm{H}_{5} \mathrm{OH}\end{array}$ & $5,37 \times 10^{11}$ & $2,014 \times 10^{8}$ & 1,1 & $1,2 \times 10^{-3}$ \\
\hline Methane, $\mathrm{CH}_{4}$ & $1,68 \times 10^{11}$ & $2,181 \times 10^{8}$ & 27,9 & $1,8 \times 10^{-2}$ \\
\hline Propane, $\mathrm{C}_{3} \mathrm{H}_{8}$ & $5,25 \times 10^{19}$ & $3,567 \times 10^{8}$ & 2,5 & $1,5 \times 10^{-5}$ \\
\hline $\begin{array}{c}\text { Vinyl chloride, } \\
\mathrm{C}_{2} \mathrm{H}_{3} \mathrm{Cl}\end{array}$ & $3,57 \times 10^{14}$ & $2,650 \times 10^{8}$ & 4,3 & $5,7 \times 10^{-4}$ \\
\hline Paper sludge, - & $8,30 \times 10^{11}$ & $2,256 \times 10^{8}$ & 14,4 & $7,2 \times 10^{-3}$ \\
\hline
\end{tabular}

The process of burning a mixture of light fraction and sludge in the boiler combustion chamber is carried out in two main stages. Fuel is introduced into the combustion chamber at regular intervals and is transported by the inclined grate assembly (Fig. 6). The first part of the process is carried out on the grid with a lack of air (the air excess factor $\lambda<1$, where $\lambda$ refers to the theoretical or stoichiometric air needed for complete oxidation of the fuel). The temperature in this part of the process is between $600{ }^{\circ} \mathrm{C}$ and $700{ }^{\circ} \mathrm{C}$, and only partial burning or pyrolysis of the fuel occurs at such conditions. In the second stage the resulting gaseous products from the pyrolysis process burn completely with the excess of air $(\lambda>1)$ and the heat is released (exothermic process). The resulting heat is used in the heat exchangers inside the boiler for water heating, its evaporation and the steam superheating.

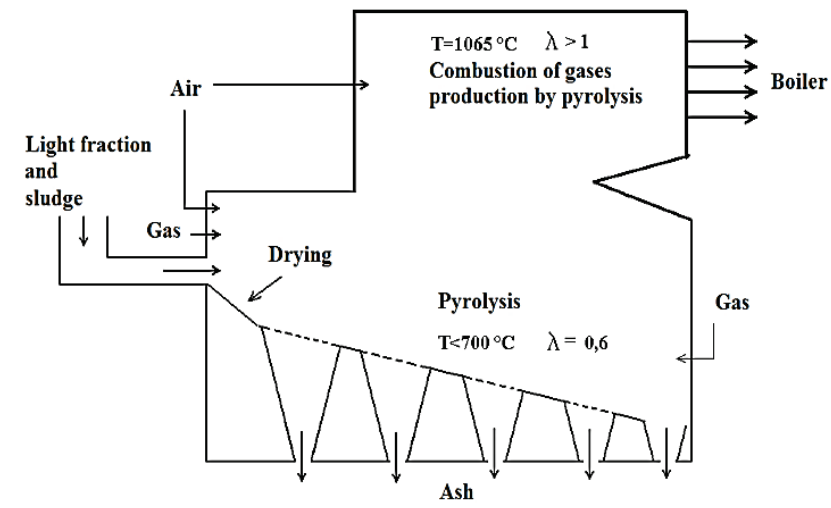

Figure 6 Schematic representation of the boiler furnace
The steam produced in the boiler at a rate of $20 \mathrm{t} / \mathrm{h}$ has a temperature of $350{ }^{\circ} \mathrm{C}$ and the pressure of $28 \mathrm{bar}$. It should be noted that even higher temperature of steam is obtainable, but it is not applied for the reason of longer lifetime of the boiler. Superheated steam is expanding in a steam turbine. After leaving the turbine at a pressure of 1,5 bar and a temperature of 125 to $140{ }^{\circ} \mathrm{C}$ steam enters the condenser where it condenses and a feeder pump returns the condensate to the boiler. One part of the produced steam can be optionally used for the heating purposes of central heating system in Celje. Steam turbine drives the generator of $2 \mathrm{MW}$ electric power. Thermal heating power of the plant is $15 \mathrm{MW}$. There is also a possibility of using the heat of air which is used for cooling in the condenser but for now it is emitted into the environment.

By-products resulting from the combustion are flue gases and ash (Fig. 7). The ash from the boiler furnace is collected under the grid as shown in Fig. 6, and then discharged into containers by belt conveyor and screw conveyor. The annual amount of this ash is about 2500 tons. There are indications that the ash could be used as an additive in asphalt road construction, but for now it is disposed off at the landfill. Ash and slag from the furnace are considered as non-hazardous waste.

Flue gases from the boiler combustion chamber have to be purified before exhausting into the environment. There is installed an efficient technology to control the combustion process which has a positive effect on reducing the number of catalytic processes for removing harmful substances from the flue gases and reduces the emissions of particulate matter (dust) in the environment.

Flue gas cleaning involves the removal of nitrogen oxides and acid gases, as well as the separation of the particles and the potential of organic substances and heavy metals. The refinement system is designed and implemented in three phases. First, the process of dry adsorption with sodium carbonate and activated charcoal is used, then follows a filter to remove particles and at the end, flue gases pass through a coke adsorbent for the separation of organic substances and the potential harmful metals. It should be emphasized that in the early beginning of the heating plant the ceramic filters were used, but because of their rapid blocking they were replaced with the bag filters. Bag filters are made of a special material resistant to the temperature of gases up to $250{ }^{\circ} \mathrm{C}$ (PTFE polytetrafluoroethylene, the trade name Teflon).

The amount of fly ash that is removed in the bag filter is about 300 to $400 \mathrm{~kg}$ per year. In order to reduce the concentration of nitrogen oxides, the recirculation of hot flue gases sprayed with ammonia is applied. The products obtained by purification of flue gases are considered as hazardous waste due to the increased metal and salt contents and need to be disposed off separately.

The problem with saturated coke from coke adsorbent is solved so that it is redirected to the entrance of the combustion chamber of the boiler where it burns together with the fuel mixture. 


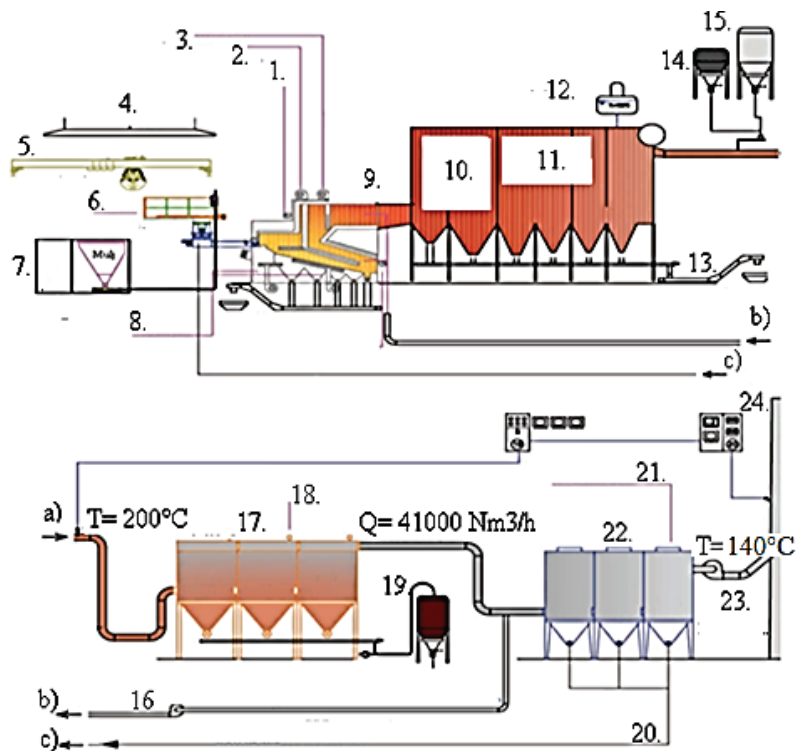

1. Gas ignition
2. Secondary air
3. Tertiary air
4. Air suction anddischarge burn
5. Crane ( 5 t/h)
6. Dosage device
7. Storage of light fraction and sluge
8. Primary air
9. Boiler furnance
10. Evaporator
11. Superheater
12. Thermal water treatment
13. Removing of ash
14. Activated carbon
15. Silo with soda
16. Flue gas recirculation $(8000 \mathrm{Nm} 3 / \mathrm{b})$
17. Bag filters ( $\left.=150^{\circ} \mathrm{C}\right)$
18. Compressed air
19. Fly ash silo
20. Worm coke
21. Coke
22. Coke adsorber

Figure7 Schematic representation of the heating plant of Celje for the energy utilization of waste

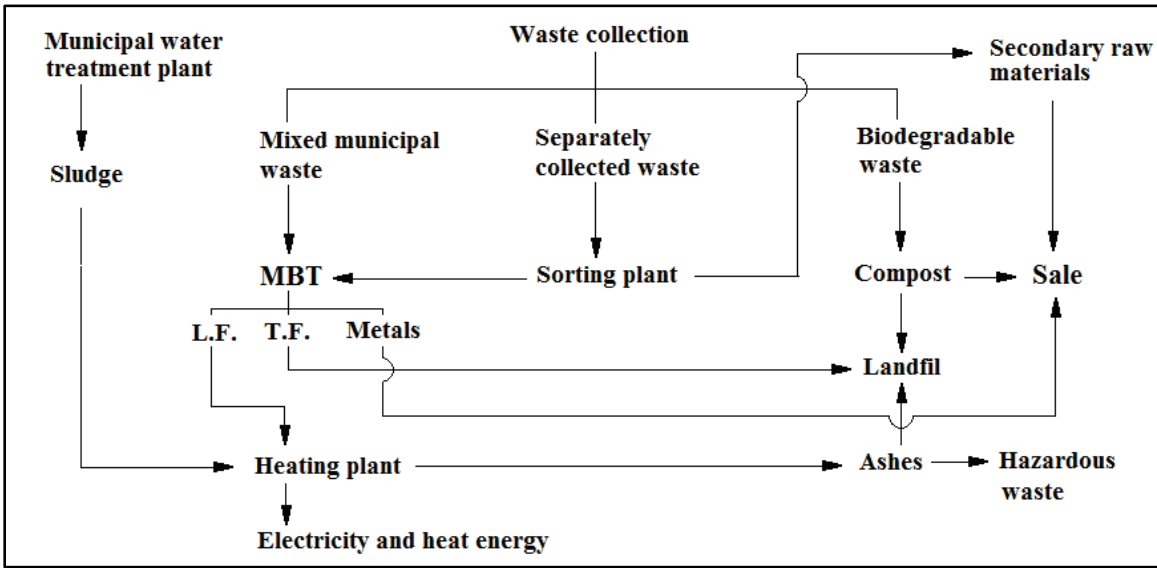

Figure 8 Schematic representation of the successful model of waste management in a regional centre

\section{Economical factors}

The price for the treatment of the mixed municipal waste is calculated on a yearly basis. In 2014, the minimum rate for mixed municipal waste treatment including subsequent incineration and landfilling and excluding V.A.T. was set at 97 EUR per ton for the users from 24 municipalities [22]. The overall waste management price including collection of all municipal waste streams for the inhabitant varies because the price is set depending on frequency of collection and the size of the bin. In Celje the standard yearly cost for individual houses with standard household size and standard bins size is around 100 EUR per person per year including V.A.T.

The final price for the inhabitants depends on many factors: on the amount of waste, scarcity of habitation, distance from treatment infrastructure, degree of correct waste separation, environmental taxes, size of financial guarantee for landfill, used percentage of plant capacity, average worker salary, energy prices, petrol prices, just to list a few of them. One factor which can be very unpredictable is raw material price and correct planning with some degree of variation is needed. Therefore the given numbers should be taken with a caution when trying to apply to the Croatian situation as specific factors can greatly affect the economics even in apparently identical situation.

\section{Generalized model of sustainable waste management}

Based on the detailed description in the paper it can be concluded that the city of Celje and the surrounding region achieve an effective and economically sustainable waste management in the region. The similar model can be proposed for the regions or cities of similar size in Croatia, but a very thorough economic evaluation has to be made in every specific case.

The schematic representation of the waste management system which can be proposed for further application is shown in Fig. 8.

\section{Conclusion}

The regional waste management system covering the needs of the city of Celje and 24 surrounding municipalities with 230000 inhabitants is described in details. The plant processes three different types of separately collected waste: biodegradable waste, mixed waste and other separately collected waste. Biodegradable 
waste is brought directly to composting, where the final product is the compost, whose better quality is sold to improve the soil while poorer quality compost is used to cover the landfill. Mixed municipal waste is processed in a mechanical biological treatment plant, where final products are light fraction, heavy fraction and metals. Light fraction is transported by trucks to the heating plant and mixed with sludge from the municipal wastewater treatment plant. The combustion of this mixture in the combustion furnace of the boiler provides electrical (2 MW) and thermal energy (15 MW). By-product of combustion, ash from the combustion chamber in an amount of about 2500 tonnes per year, is transported back to the landfill, and flying ash from the bag filter (PM10 particles) in an amount of about 300 to $400 \mathrm{~kg}$ per year must be disposed off as hazardous waste. The heavy fraction from MBT plant is deposited at the landfill, and separated metals are sold to the purchasers of secondary raw materials. Other separately collected waste is transported to the sorting plant where it is additionally sorted. Isolated parts of plastics and metals are sold and a small residue of unsorted waste is forwarded to the MBT plant where it is treated with the municipal mixed waste. According to this successful example of a sustainable waste management system a generalized schematic was derived and it is suggested to implement it for similar reginal waste management systems in Croatia.

\section{References}

[1] Leskošek, M.; Svetičič, J.; Marš, S. Regionalni centar za gospodarenje otpadom u Celju. // X. Međunarodni simpozij gospodarenja otpadom / Zagreb, 2008, pp. 230-234.

[2] Kristoforović-Ilić, M.; Radovanović, M.; Vajagić, L.; Jevtić, Z.; Folić, R.; Krnjetin, Z.; Obrknežev, R. Komunalna Higijena, Prometej, Novi Sad, 1998.

[3] Orašanin, R. Studija za izbor Sistema suvremenog zbrinjavanja otpadaka za Zagreb. // Fond stručne dokumentacije, Industrijski projektni zavod, Zagreb 1978:

[4] Zanoni, A. E. Ground Water Pollution and Sanitary landfills-Agricurtural Review. // Ground Water. 10, 1(1972), pp. 3-16. https://doi.org/10.1111/j.1745-6584.1972.tb02895.x

[5] Mayer, D.; Markovac, Z.; Hidrologija područja smetlišta Jakuševac (Zagreb). // Rudarskogeološkonaftni zbornik. 4(1992), pp. 51- 21.

[6] Tofexi, E.; Tsarpali, V.; Efhimiou, I.; Sophia, M-S.; Vlastos, D.; Dailianis, S. Environmental and human risk assessment of landfill leachate: An integrated approach with the use of cytotoxic and genotoxic stress indices in mussel and human cells. // Journal of Hazardous Materials. 260, (2013), pp. 593-601. https://doi.org/10.1016/j.jhazmat.2013.05.054

[7] Tsarpali, V.; Dailianis, S. Investigation of landfill leachate toxic potency: An integrated approach with the use of stress indices in tissues of mussels, Aquatic Toxicology, 124-125 (2012), pp. 58-65. https://doi.org/10.1016/j.aquatox.2012.07.008

[8] Oliveria, L. F.; Silva, S. M. C. P.; Martinez, C. B. R. Assessment of domestic landfill leachate toxicity to the Asian clam Corbicula fluminea via biomarkers. // Ecotoxicology and Environmental Safety. 103, (2014) pp. 17-23. https://doi.org/10.1016/j.ecoenv.2014.01.034

[9] Košutić. K. Fizikalnokemijski procesi obrade voda // Skripta s predavanja, Fakultet kemijskog inženjerstva i tehnologije / Zagreb 2011.
[10] Judd S. The MBR book - Principles and Applications and Water and Wastewater Treatment. // Elsevier, London, 2006.

[11] http://bs.scribd.com/doc/91709473/MBO-sustav (13.12.2013)

[12] Burnley, S.; Phillips, R.; Coleman, T.; Rampling, T. Energy implications of the thermal recovery of biodegradable municipal waste materials in the United Kingdom. // Waste Management. 31, (2011), pp. 1949-1959. https://doi.org/10.1016/j.wasman.2011.04.015

[13] Chang, Y-H.; Chen, W. C.; Chang, N-B. Comparative evaluation of RDF and MSW incineration. // Journal of Hazardous Materials. 58, (1998), pp. 33-45. https://doi.org/10.1016/S0304-3894(97)00118-0

[14] http://www.mbt.landfill-site.com/ (13. 12. 2013)

[15] http://www.foe.co.uk/sites/default/files/downloads/ changing climate.pdf (13.12.2013)

[16] Zhang, H.; Zhang, D-Q.; Jin, T-F.; He, P. J. Environmental and economic assessment of combined biostabilization and landfill for municipal solid waste. // Journal of Environmental Management. 92, (2011), pp. 2533-2538. https://doi.org/10.1016/j.jenvman.2011.05.018

[17] Scaglia, B.; Salati, S.; Di Gregorio, A.; Carrera, A.; Tambone, F.; Adani, F. Short Mechanical Biological treatment of municipal solid waste allows landfill impact reduction saving waste energy content. // Bioresource Technology. 143, (2013), pp. 131-138. https://doi.org/10.1016/j.biortech.2013.05.051

[18] Fricke, K.; Bidlingmaier, W.; Mechanical biological treatment of residual waste, adequate landfilling techniques and rehabilitationof old landfill deposits. // $20^{\circ}$ Congreso Brasilerio de, engenharia sanitaria e ambiental / Brasil, 1999, pp. 4280-4292.

[19] Zavod za zdravstveno varstvo Celje. Sortirna analiza odpadka: mešani komunalni odpadki, junij 2011 /Celje, 2011, pp. 8.

[20] Prelec, Z. Obrada i zbrinjavanje otpada. // Inženjerstvo zaštite okoliša / Rijeka, 2013, pp. 50.

[21] Yong Ho, Y.; Sang Done, K.; Jong Min, L.; KeunHoo, L. Kinetic studies of dehydration, pyrolysis and combustion of paper sludge. // Energy. 27, (2002), pp. 457-469. https://doi.org/10.1016/S0360-5442(01)00097-4

[22] Simbio, d.o.o. Cenik obdelave odpadkov v RCERO Celje / Celje, 2014, pp. 1.

\section{Authors' addresses}

Bojan Plavac mag. ing. univ. spec, prof. dr. sc. Veljko Filipan,

izv. prof. dr. sc. Igor Sutlović

University of Zagreb,

Faculty of Chemical Engineering and Technology

Marulićevtrg 19, 10000 Zagreb, Croatia

Dept. of Thermodynamics, Mechanical Engineering and Energy Savska cesta 16, HR-10000 Zagreb, Croatia +38514597109

E-mail: bojan.plavac@gmail.com

Jure Svetičič, univ. dipl. mikrobiol.

SIMBIO, družba za ravnanje z odpadki d.o.o.

Teharskacesta 49, 3000 Celje, Slovenia

+38631349543

E-mail: jure.sveticic@simbio.si 